\title{
Technical Education as a Vital Tool for Skill Acquisition through Guidance and Counseling for Nation Building
}

\author{
Alexander Gbenga Ogundele ${ }^{1, *}$, Christianah Toyin Feyisetan ${ }^{2}$, Gana Peters Shaaba ${ }^{3}$ \\ ${ }^{1}$ Metalwork Technology Department, Kwara State College Of Education (Technical), Lafiagi, Nigeria \\ ${ }^{2}$ Department Of Educational Psychology, Emmanuel Alayande College of Education, Oyo, Oyo State, Nigeria \\ ${ }^{3}$ Automobile Technology Department, Kwara State College of Education (Technical), Lafiagi, Nigeria \\ *Corresponding author: alexnig2003@yahoo.com
}

Received January 09, 2014; Revised January 15, 2014; Accepted February 07, 2014

\begin{abstract}
Guidance and Counseling provides a platform that an individual can use to acquire Skill with the right attitudes which are necessary for entrance and progress into an occupation. When skills are acquired in any occupation, it will provide and improve the standard of living with the insurance against poverty, thereby sustaining national development in terms of skill acquisition. People who do not have the guide to acquire skills and knowledge that are relevant to a particular job cannot take up jobs that are readily available. This paper examines technical education, skill acquisition to nation building, guidance and counseling and its impact on technical education. It also recommends among others that the wide gap between the classroom and the industry should be bridged by skill acquisition policy in every ramification. In fact, the ration of theoretical to practical should be 30:70 because you learn what you see, you remember what you touch.
\end{abstract}

Keywords: Technical Education, guidance and counseling, skill acquisition, Nation Building

Cite This Article: Alexander Gbenga Ogundele, Christianah Toyin Feyisetan, and Gana Peters Shaaba, "Technical Education as a Vital Tool for Skill Acquisition through Guidance and Counseling for Nation Building.” American Journal of Educational Research, vol. 2, no. 1 (2014): 50-53. doi: 10.12691/education-2-1-9.

\section{Introduction}

It is quite glaring that no nation can develop without proper exploitation of her natural resources for the benefit of the people. The development of infrastructures (roads, railways, power, pipe borne water, communications, health care, etc.) is of paramount value to enhance the economy of such a nation. In order to make the economy grow, strong and stable in this era of global economic meltdown, we must increase the productivity of all factors of production (land, labor, capital, etc). This will inevitably lead to the development of the industrials, agricultural, tertiary health care and export sector of the economy. It will equally increase employment rate, national income and growth rate of the economy. Students today graduate from college without having enough skill to cope with their new jobs. This view is supported from the view of Akano in [2] that there is a skill gap in the area of computer engineering. He went further that the information and technology industry is confronted by knowledge deficiency noting that university graduates are only familiar with theory. Okafor in [2] asserts that there is a big gulf between what the school offer and the demand of employers [7]. opines that employers want employees who can use their abilities and skills to evolve the organization. The place of skill acquisition cannot be over emphasized in the rapid development of other sectors of the economy. For this to be actualized polices and goals on skill acquisition must be put in a place and well implemented.

\section{Technical Education}

By the views of [1] Technical Education is, "an aspect of education, which leads to the acquisition of practical, basic scientific knowledge, which involves special manipulative skills, creative minds, and attitudes relating to occupations in various sectors of the economic and social life”. In line with this mindset, according to the [6] the goals of technical education shall be among others, to:

i. provide trained manpower in applied science, technology and commerce particularly at subprofessional grades.

ii. provide the technical knowledge and vocational skills necessary for agricultural, industrial, commercial, and economic development.

iii. give training and impact necessary skills leading to the production of craftsmen, technicians, and skilled personnel who will be enterprising and self-reliant.

\subsection{Guidance \& Counseling}

Guidance is instructive and directive in nature, which can be given by anybody that has to follow a procedure. Reference [6] defines guidance as "a process in which the counselor assists the counselee to make interpretation of facts relating to choice plan of adjustment." Counseling in other words helps an individual to realize one's potentials, 
capabilities, interests, abilities, needs, and aspirations in order to formulate one's own goals and make adequate plans for realizing thus goals. In addition, [9] stresses that the function of counseling is also to facilitate normal development and prevent great frustration, activities and stresses that might arise from psychological changes.

Thus, [9] maintains that the concept of guidance and counseling represent an extension of the role of the school to the life of the students and this implies the assumption that any guidance and counseling programme does more as a means to academic tutoring. It is a help given to each student in an effort to assist in personal growth in a way that is most beneficial to individual and the society.

Furthermore, [15] presents counseling as a learning oriented process which usually occurs in the literal relationship with the aim of helping the person to learn to put such understanding to effective use for self and society. Reference [8] on the other hand, views counseling as a process in which the helper expresses care and concern toward the person with a problem to facilitate that person's growth and positive changes through understanding.

\subsection{Impact of Guidance and Counseling on Technical Education}

In as much as technical education is an education that prepares student for specific trade, craft, and career at various levels to prepare them for future so that they can be useful to themselves and the society where they belong. Guidance and Counseling thus play significant roles in technical education such as:

a). It brings about awareness to the student, as they will discover the hidden potentials in them, their strengths, and how to work on their weaknesses to have a fulfilled future.

b). It will enable them to have a sense of direction as to which specific skill they want to pursue rather than following their friend's suggestion to them.

c). Guidance and counseling enable students to discover their own talents, strength and weaknesses, family expectation and national requirements to sort out the personal relevance of educational and vocational options available.

d). It enables them to understand the means of gaining entry, the life of the worker and the reward of the jobs.

e). It enables them to overcome the defeating behaviors, gain self-confidence, and learn life skills.

f). It also empowers them to cope with the reactions of job loss, of anger, depression, frustration, and apathy and learn to take alternative measure when current job is in jeopardy.

g). It exposes the student to the opportunity of developing the transition skills of continuously developing one's competencies in the face of adversity and opportunity, obtain information on the transferability of one's skills to new opportunities.

\section{Skills Acquisition}

From all indication, Skill is the ability to do something well, usually gained through training or experience that is needed while acquisition is the act of getting new knowledge, skill, that can be transferable on and to the job. This skill can be obtained through education, training or experience that will inculcate into the individual how to carry out or discharge effective responsibilities very well with the new knowledge. This is because any work carried out by skilled people cannot be compared with those tasks performed by unskilled people.

The only irreplaceable capital and organization processes are the knowledge and ability of its people. The productivity of that capital depends on how effectively people share their competence with those who can use it. When a skill is acquired in any discipline, it is assumed that the future gains that would result from it are of greater importance in terms of productivity.

\subsection{Skill Acquisition to Nation Building}

Reference [5] states that the impacts of economic calamity on nations depend on their level of development and effectiveness. Nigeria needs people who are skilled in modern agriculture methods to handle the use of modern equipment, new techniques in seed planting, land cultivation, harvesting and storage. These people will ensure that adequate food is produced for Nigerian's increasing population.

Nigerian is rapidly expanding her roads network system to improve the movement of goods and services. Such construction jobs require not only expert and dedicated workers, but skilled technicians who are able to operate and service the heavy duty equipment used in road construction. Modern industries are being established in all parts of the country. These industries need skilled and well-trained workers to ensure that goods manufactured in Nigeria are as good as those manufactured in other parts of the world.

People need skills to operate and administered government and industrial operations. The expansions of both the public and private sectors in Nigeria means that more skilled workers in office management, accounting, typing and short-hand are required to ensure that accurate records are kept and that administrative efficiency is maintained. Nigeria roads are full of all kinds of vehicles which assist in the economic development of the country by ensuring that goods and services are moved quickly and safely from one part of the country to another. These vehicles need efficient operatives and skilled technicians to ensure that they are operated safely and that their useful life is extended.

Skill acquisition is needed in the education sector. It contributes to the development of the nation's human capital and is seen as essential for preparing one for employment. Thus an educated man is expected to manifest worthwhile disposition in the society, for his own development and the development of the society. Reference [10] share the view that the productive capacity of any nation depends solely on her ability to recognize the capacity of manpower. The development of ideas, science advancement, technological breakthrough, economic development, political stability, e.t.c, is made possible by educational theories and practices.

Whatever the skill, attitudes, competencies, knowledge and understanding one acquires will enhance the development of the individual and the nation. According 
to [6], one of the goals of education is the acquisition of appropriate skills and the development of mental, physical and social abilities and competencies as equipment for the individual to live and contribute to the development of his society. Reference [11] submits that;

'we need skilled personnel who will be enterprising and self reliant. We need skilled people who can understand and adapts to changes in the increasing complexity of technology. We need people who can apply scientific knowledge to the improvement and as solution to environmental challenges for the use and conveniences of man'.

\subsection{Significance of Skill Acquisition}

Two decades after Nigeria's independence, opportunities for employment abound for Nigerian graduates. In facts, it was the case that each recent graduate had at least three jobs from which to choose. Furthermore, the movement from school to job was virtually automatic. Today, it is very pathetic that the story line has changed as there is a disconnection between the world of learning and the world of work. Each job that appears in the labor market is now pursued by many old and new unemployed individuals because of the growing population. Reference [4] assert that there are increasingly fewer occupational opportunities for the unfortunate youths who lack the basic skills and knowledge. By implication, unemployment rate will increase which will be a menace to the society, thereby, slowing down the pace of development because of untapped potentials or talents that are lying idle. Therefore, there is the need for the unemployed individuals to learn and acquire new skills which would make them self-employed by setting up their own businesses to create jobs for others too. In some cases, where the few ones get a job, they are trained to acquire special skills before they can go ahead with the new job. Reference [11] opines that skill acquisition help people already on a job; intending to work in any of the varieties of occupations needed by the society. There is no job that does not require its own skill for manpower development.

The importance of skill acquisition to the development of the nation is of no small measure. Many of these construction industries, manufacturing industries, production industries, etc, are in daily need of trained personnel, technicians, technologists, engineers, etc, to carry out one job or the other. Reference [13] is of the view that our industries need skilled and well-trained workers to ensure that goods manufactured in Nigeria are as good as those manufactured in other parts of the world.

\subsection{Impact of Skill Acquisition to Nation Building}

The skill acquired by will prepare young people for any specific job with a lifelong opportunity for self development. This is because there will be competency, interest and job satisfaction to the highly skilled person to effectively and efficiently carry out that job successfully for higher productivity.

The acquisition of skills will prepare the individual to fit in readily to employment in all sectors of the economy.

Skill acquisition can help in the formulation of ideas, their integration for national development and the interaction of persons and ideas.
Prompt application of appropriate skill acquired would no doubt help to solve many of the perennial challenges arising from inadequacies and deficiencies of the traditional methods of teaching related subjects in our various institutions of learning.

The acquisition of skills for a particular job will provide for people who could apply relevant knowledge to be able to make positive changes within the society. Skill acquisition in other words could advance the nation in the following ways:

A well trained worker will be much more productive within the society, if he/she receives the required guidance in picking a career. Such an individual will no longer be a burden to the nation, it will make an individual to cultivate better attitude to work

Any individual who acquires skill will be able to show case his/her talents, make intelligent use of the brain in terms of new discoveries and innovation that will even upgrade individual status within the society.

When a skill is acquired in any discipline, it is assumed that the future gains that would result from it are of greater significance to productivity.

The growing concern over globalization, among other things, has made the acquisition of lifelong skills imperative for all categories of people. This is considered very important for future professionals' growth because it will determines how successful and productive a person will be in the work place. Reference [14] observes that human capital is created when they acquire transferable skills that can be applied in many settings and occupations. It is an important index of sustainable development of any nation. In view of this, [14] considers it as both a social prerogative and an economic necessity. With skill acquisition, one acquires capabilities to compete favorably within the context of globalization.

\section{Conclusions}

The world is embracing a knowledge-based economy. We need to acquire more knowledge and skills for economic growth because every sector needs better skills to keep it running. By accommodating this, we need to equip the youths and working adults with employment skills and knowledge to meet the increasing demand for technical manpower by various sectors of the nation's economy either through potential guidance and counseling formal, non-formal or informal training.

\section{Recommendations}

In the light of the above, the following recommendations are made

1. Entrepreneurial development must be mandated in our schools to solve the problem of economic meltdown in our country.

2. Recruitment of more technicians should be encourage to gear their interest up Government, through the ministry of education should mandate these entrepreneurial skills into the school curriculum.

3. There should be more practical work to complement theory in our tertiary institutions of learning, to provide skilled labor for the economy. 
4. Enough training facilities need to be provided to replace obsolete training equipment in this era of digitalization, in order to meet modern standard.

5. The wide gap between the classroom and the industry should be bridged by skill acquisition policy in every ramification. In fact, the ration of theoretical to practical should be 30:70 because you learn what you see, you remember what you touch.

6. Secondary and post secondary institutions curricula should be developed to suit the demands of labor market.

7. The Student Industrial Work Experience Scheme (SIWES) programme should be extended to the secondary schools during school vacation period while the fresh graduates go for one year industrial training after graduation.

8. Uneducated youths should be equipped with such skills as repair skills, maintenance skills, technical skills know how, Accounting and record keeping skills and procedures of operation skills in order to be self reliant.

9. Government should look into and improve programs that will encourage skill acquisition for our youths.

\section{References}

[1] Aina, J. K., Ogundele, A. G., Olanipekun, S. S., "Students' Proficiency in English Language Relationship with Academic Performance in Science and Technical Education.” American Journal of Educational Research 1, No. 9 (2013): 355-358. January 2014.

[2] Ajibade, A, "More graduates, less skills," November 2009. [Online]. Available: http:// www.skill/com dated 30/11/2009.
[3] Anderson, D. "Navigating the Rapids: The Role of Education and Career information and Guidance in Transitions between Education and Work: A journal of Vocational Education and Training. Vol. 5 (3) pp 371-399. 1999.

[4] Datol, I.G. and Padung, L.L., Vocational and Technical Education - Away out of Nigerians future generation, Zimleck Comms. Jos, 2002.

[5] Dike, V. (2009). Global-economic crisis and power, http:// www.nigeriavillagesquare.com.

[6] Federal Republic of Nigeria, National Policy on Education, NERDC Press, Yaba-Lagos. 2004 Revised, 8.

[7] Harvey, L. \& Bowers-Brown, T. The Employability of Graduates: Cross Comparison; Paper presented at DFES Research Conference 2003, London.

[8] Kolo, F.D. Conditions for an effective counseling process, Rasper Vicko Consultancy Services , Zaria, 2003, 23.

[9] Longe, O.O. Truancy and absenteeism as correlates of juvenile delinquency: Implication for counseling Services. The Lagos Counsellor: Official Publication of the Counseling Association of Nigeria (CASSON), 3, (1), 41-49. 2010.

[10] Ogunbote, Shefiu; Zosu, S. J. \& Ajibade, T. O. UBE: The impact of Technology Education for Nation Building. Nigerian Association of Teachers of Technology Journal, Vol. 8, pp 108. October, 2006.

[11] Ogundele, A. G. Higher education and employability in the international labor market: The need for technical education. Retrieved fromwww.cefwa.net/compilation_for_proceedings.pdf Nigeria. pp219. February, 2010.

[12] Ojo, C.O.E. Perpetual use of counseling service in curbing examination malpractice in tertiary institution. The university of Ibadan as a case study. M. Ed Thesis Department of Guidance and Counseling, University of Ibadan, Oyo State. 2001.

[13] Okoro, O. M. Principles and Methods in Vocational and Technical Education, University Trust Publisher, Nsukka 1993, 10-11; pp 15, 88.

[14] Shaffer, L. S. "A Human Capital Approach to Academic Advising”. National Academic Advising Association Journal.17. pp. 5-12. 1997.

[15] UNESCO. The National Research Center for Career and Technical Education University of Louisville, College of Education and Human Development, Louisville, KY 40292. Pp. 7-8. 2012. 